\section{Relationship between Antioxi- dants and the Development of the Periodontal Disease}

\author{
Rudrakshi C*, Prabhuji MLV, Parween S and Jyothsna S \\ Department of Periodontology, Krishnadevaraya College of Dental Scienc-
} es \& Hospital, Hunasamaranahalli, Bangalore

\begin{abstract}
The role of oxidative stress linking the free radical damage at the cellular level causes premature aging, including periodontal disease. To overcome this, it is important to explore the role of host specifically with regard to antioxidant status along with conventional periodontal therapy. Periodontal counselling and supplementation may very well reduce inflammation and thereby enhance outcomes of conventional periodontal therapy. The purpose of this review is to summarize available research in the role of antioxidants as an adjunct to periodontal therapy.

Keywords: Antioxidants; Free radical; Inflammation; Periodontal therapy

Key Messages: Antioxidants have shown to have beneficial outcome when used as adjunct to traditional periodontal therapy. Implication of antioxidants has promising results in future.
\end{abstract}

\section{Introduction}

Periodontitis is a chronic inflammatory disease caused primarily by bacteria in dental plaque, affecting the supporting structures of the teeth. Specific periodontal pathogens such as the gram-negative anaerobic bacteria inhabiting within the sub-gingival plaque are associated with the progressive form of the disease. Although bacteria are the major etiological agents, the host immune response to these bacteria is of fundamental importance. Hence, it is evident that periodontitis is a multifactorial disease, affiliates with specific microorganisms, social and behavioral factors, genetic or epigenetic trait, all of which are modulated and controlled by the underlying immune and inflammatory responses of the host [1].

*Corresponding author: Rudrakshi C, Department of Periodontology, Krishnadevaraya College of Dental Sciences \& Hospital, Hunasamaranahalli, Bangalore, Tel: +91 9448057407; E-mail: drrudrakshi@rediffmail.com

Citation: Rudrakshi C, Prabhuji MLV, Parween S, Jyothsna S (2017) Relationship between Antioxidants and the Development of the Periodontal Disease. J Cytol Tissue Biol 4: 016.

Received: June 02, 2017; Accepted: August 12, 2017; Published: August 25, 2017
The recent focus on the progression of periodontitis is on the molecular aspects of host modulation. The discovery of the role of free radicals in chronic disease is as important as the discovery of the role of microorganism in inflammatory disease [2].

Free radicals \& Reactive Oxygen Species (ROS) production is an essential component of the host response for immune system, prostaglandin biosynthesis, anti-bacterial biosynthesis and variety of insults like trauma/burns [3]. Besides, the physiological system, ROS generation are induced by several exogenous factors such as pollution, smoke, radiation, pesticides and drug consumption. Major producers of ROS are mitochondrial cytochrome $\mathrm{P}-450$ reactions, peroxisomal fatty acid metabolism and NADPH oxidase activity [4]. An imbalance between the ROS production and anti-oxidant mechanism leads to oxidative stress. Oxidative stress has been associated with both onset of periodontal destruction and systemic inflammation $[5,6]$.

Primary immune response against periodontal pathogens is elevated numbers of neutrophils seen in connective tissue, junctional epithelium (50\%) and gingival crevicular fluid (90\%) and it can cause loss of epithelial cell-cell attachment in junctional epithelium (>60\%) leading to apical shift of junctional epithelium [7].

Neutrophil have several mechanisms for controlling bacterial invasion which includes both intracellular and extracellular oxidative and non-oxidative killing mechanisms [8]. When neutrophils and macrophages get stimulated by a phagocytic stimulus, produces a 'respiratory burst', which is characterized by an increase in oxygen consumption, activation of the Hexose-Monophosphate (HMP) shunt and generation of Free Radicals (FR), Reactive Oxygen Species (ROS) and their metabolic products. At sites of chronic inflammation (periodontium in case of periodontitis), there is considerable over production of FR and reactive species.

Research with scientific evidence confirmed that inflammation in the oral tissues especially that associated with periodontitis can be a factor in chronic illness such as cardio and cerebro vascular diseases $[9,10]$, diabetes mellitus, rheumatoid arthritis, advance pregnancy outcomes and a growing list of other conditions such as cancer, psoriasis, chronic kidney disease and anemia. Several hypotheses proposed to describe the interlinking between periodontal diseases and systemic diseases. One of the explanations is imbalance between systemic oxidants and antioxidants [11-13]. "An antioxidant is any substance that, when present at low concentrations compared to those of an oxidizable substrate, significantly delays or prevents oxidation of that substrate" [14].

Hence the concept of inhibition of building up oxidative stress within cells through anti-oxidative therapy is implicated in inflammatory disorders and periodontitis along with gold standard therapy for periodontitis is through removal of subgingival biofilm through scaling and root planing has shown to be advantageous. The present article reviews on the comprehensive appraisal of the newer aspects of anti-oxidative therapy and it's applications in Periodontology (Figure 1). 
Citation: Rudrakshi C, Prabhuji MLV, Parween S, Jyothsna S (2017) Relationship between Antioxidants and the Development of the Periodontal Disease. J Cytol Tissue Biol 4: 016.

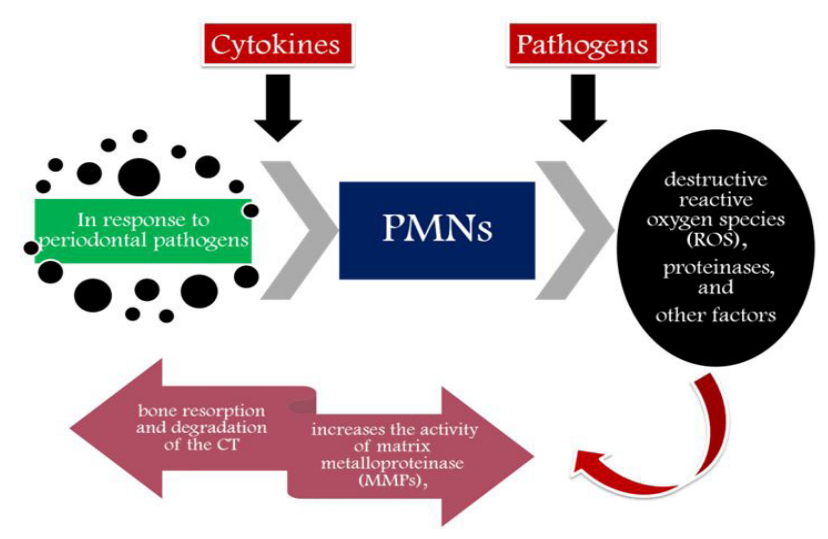

Figure 1: Role of polymorphopneutrophils.

\section{Reactive Oxygen Species (ROS)}

Every day, numerous free radicals and ROS are produced in each cell by various exogenous and endogenous sources and these ROS are counteracted or balanced by anti-oxidants present within each cell, there by prevents oxidative stress build up. Reactive oxygen species and their sources are enumerated in table 1.

Recent literature postulate that, non-radicals which have the capability of radical transformation in the extra- and intracellular environment (singlet oxygen, hydrogen peroxide and hypochlorous acid) are grouped under reactive oxygen species category $[15,16]$. Tissue damage by ROS $[5,15,17]$ (Table 2 ).

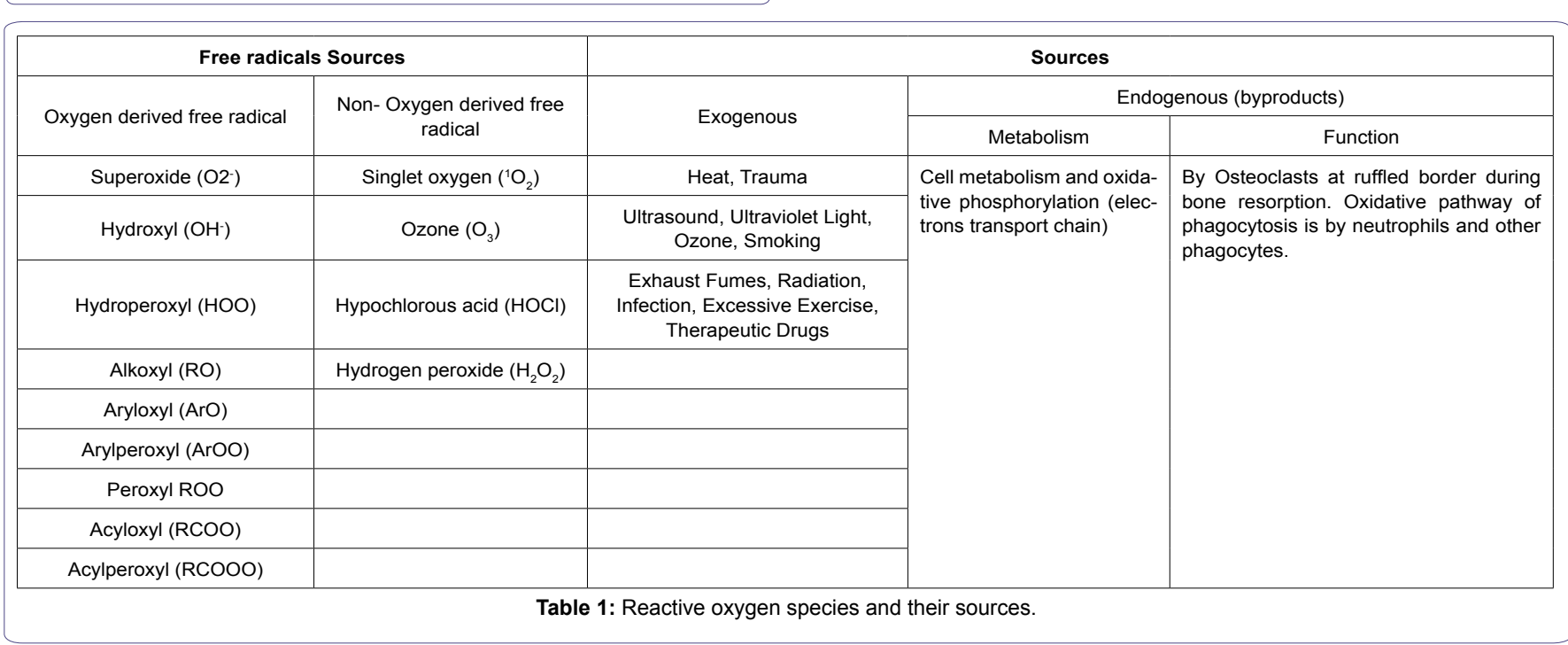

\begin{tabular}{|c|c|c|c|}
\hline ROS (Mainly Hydroxyl and peroxynitrate anion) & Target molecule & Example & Effects \\
\hline \multirow{5}{*}{ 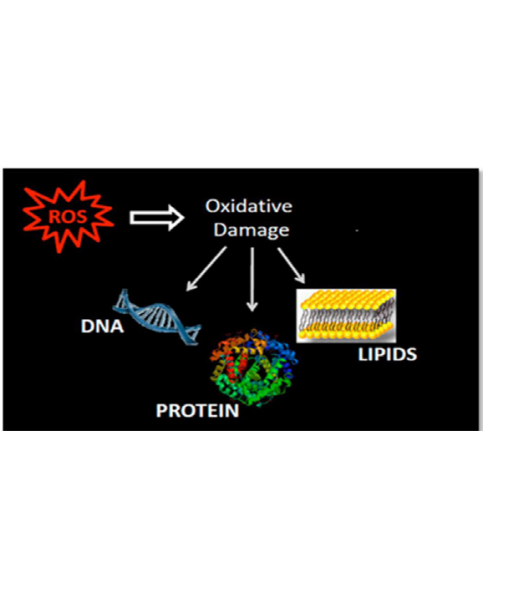 } & Protein & $\begin{array}{l}\text { Gingival hyaluronic acid and } \\
\text { Proteoglycans }\end{array}$ & $\begin{array}{ll}\text { - } & \text { Folding/unfolding, Fragmentation } \\
\text { - } & \text { Protease degradation of the modified protein } \\
\text { - } & \text { pormation of protein radicals and protein bond ROS } \\
\text { - } & \text { Formation of stable end products (acetaldehydes) }\end{array}$ \\
\hline & Lipid & $\begin{array}{l}\text { Cell membrane (activation of } \\
\text { cyclooxygenases and lipo-ox- } \\
\text { ygenases pathways) }\end{array}$ & $\begin{array}{l}\text { Peroxidation and formation of products these are bioac- } \\
\text { tive molecules, Conjugated dienes } \\
\text { Lipid Proxides, Aldehydes } \\
\text { Volatile-hydrocarbons, Prostagladin-E2(PG-E2) produc- } \\
\text { tion } \\
\text { eg: Malondialdehyde, Acrolein, Isoprostanes and Neuropros- } \\
\text { tanes }\end{array}$ \\
\hline & \multirow{2}{*}{ DNA } & & $\begin{array}{l}\text { Strand breaks, Base pair mutations, Deletions, Inser- } \\
\text { tions, conversion of guanine to 8- hydroxyguanine, } \\
\text { Nicking and Sequence amplifications. }\end{array}$ \\
\hline & & $\begin{array}{l}\text { Activating nuclear factor } k B \\
\text { (NFkB) }\end{array}$ & $\begin{array}{l}\text { Stimulation of pro-inflammatory cytokine release by monocytes } \\
\text { and macrophages }\end{array}$ \\
\hline & Enzymes & $\begin{array}{l}\text { Antiproteases such as } \\
\alpha-1 \text { antitrypsin }\end{array}$ & Oxidation \\
\hline Superoxide and hydrogen peroxide & Cells & Osteoclast activation & Bone resorption \\
\hline
\end{tabular}


Citation: Rudrakshi C, Prabhuji MLV, Parween S, Jyothsna S (2017) Relationship between Antioxidants and the Development of the Periodontal Disease. J Cytol Tissue Biol 4: 016.

Halliwell established 4 criteria for causal relationship between ROS and disease [18];

1. ROS or the oxidative damage caused must be present at the site of injury.

2. The time course of ROS formation or the oxidative damage caused should occur before or at the same time as tissue injury.

3. Direct application of ROS over a relevant time course to tissues at concentrations found in vivo should reproduce damage similar to that observed in the diseased tissue.

4. Removing or inhibiting ROS formation should decrease tissue damage to an extent related to their antioxidant action in vivo.

Growing evidence exist in causal relationship between oxidative stress and periodontitis [19] (Table 3).

\begin{tabular}{|c|c|c|}
\hline $\begin{array}{l}\text { Targeted Periodontal } \\
\text { tissue }\end{array}$ & Reaction of ROS & Effect \\
\hline Ground substance & $\begin{array}{l}\text { Depolymerization and Deg- } \\
\text { radation (non-sulfated gly- } \\
\text { cosaminoglycans are more } \\
\text { susceptible than sulfated) }\end{array}$ & \multirow{4}{*}{$\begin{array}{l}\text { All these events } \\
\text { leads to periodontal } \\
\text { tissue destruction } \\
\text { (Figure 2) and al- } \\
\text { veolar bone resorp- } \\
\text { tion }\end{array}$} \\
\hline Collagen & Collagenolysis & \\
\hline $\begin{array}{l}\text { Monocytes and macro- } \\
\text { phages }\end{array}$ & $\begin{array}{l}\text { Stimulation of excessive } \\
\text { pro-inflammatory cytokine }\end{array}$ & \\
\hline Lipid peroxidation & $\begin{array}{l}\text { PG-E2 production leads to } \\
\text { bone resorption }\end{array}$ & \\
\hline
\end{tabular}

Table 3: Reactive oxygen species on periodontal tissues.

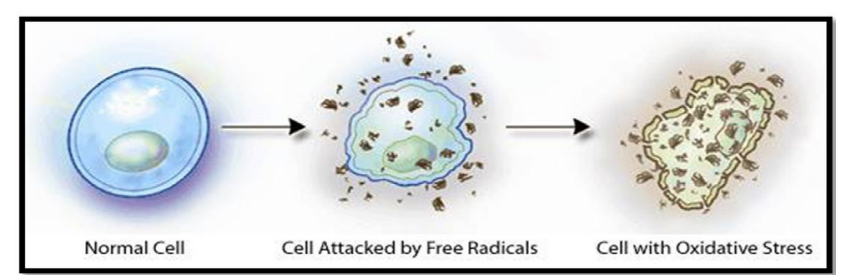

Figure 2: Periodontal tissue destruction by ROS [20].

\section{Evidence suggesting causal relationship between ROS and periodontitis}

It is more than a decade the physiological and pathological roles of ROS in the development of periodontitis have been studied

Chapple and Matthews postulated that periodontal tissue destruction results in increased production of ROS and increased ratio between elastase and lactoferrin by peripheral neutrophils [5].

Agnihotri have been reported that increased levels of ROS in smokers was responsible for excessive periodontal tissue destruction [21].

Patil et al., have reported that the severity of tissue destruction due to excessive ROS is more when periodontal disease is associated with type $2 \mathrm{DM}$, indicating that oxidative stress is common factor involved in tissue destruction [22].

Di Meo et al., suggested that low levels of ROS are beneficial, but excessive generation or antioxidant deficiency results in periodontal tissue destruction [23].
Liu et al., He et al., have shown the potential link between ROS and autophagy in periodontitis $[16,24]$.

\section{Antioxidants (AO)}

The concept of inhibition of building up oxidative stress within cells through anti-oxidative therapy is implicated in inflammatory disorders and periodontitis. Antioxidants are agents which scavenge free radicals or otherwise reactive oxygen species, thereby preventing damage caused by them. Antioxidant therapy as adjunct to conventional treatments such as scaling and root planing has shown to be advantageous. Antioxidant can be classified in the following way (Table 4).

\begin{tabular}{|c|c|c|}
\hline SI.no & Based on & Examples \\
\hline 1 & \multicolumn{2}{|l|}{ Mode of action } \\
\hline & \multirow[t]{3}{*}{ Preventive } & $\begin{array}{l}\text { Suppress the formation of free radicals: Catalase, } \\
\text { Glutathione peroxidase, and Serum transferase }\end{array}$ \\
\hline & & $\begin{array}{l}\text { Metal ion sequestrators- Albumin, Lactoferrin, } \\
\text { Transferrin, Ceruloplasmin, Uric acid, Polyphenolic } \\
\text { flavenoids }\end{array}$ \\
\hline & & $\begin{array}{l}\text { Quenching of active oxygen: Superoxide dismutase, } \\
\text { Carotenoids }\end{array}$ \\
\hline & $\begin{array}{l}\text { Scavenging } \\
\text { (Chain breaking) }\end{array}$ & $\begin{array}{l}\text { Ascorbate, Carotenoids, Uric acid, Vitamin E, Biliru- } \\
\text { bin, Reduced glutathione \& other }\end{array}$ \\
\hline \multirow[t]{4}{*}{2} & \multicolumn{2}{|l|}{ Location } \\
\hline & Intracellular & $\begin{array}{l}\text { Superoxide dismutase enzymes- } 1 \& 2 \text {, Catalase, } \\
\text { Glutathione peroxidase, DNA repair enzymes \& Re- } \\
\text { duced glutathione. }\end{array}$ \\
\hline & Extracellular & $\begin{array}{l}\text { Superoxide dismutase enzyme- } 3 \text {, Slenium glutathi- } \\
\text { one peroxidase, Reduced Glutathuione, }\end{array}$ \\
\hline & $\begin{array}{l}\text { Membrane } \\
\text { associated }\end{array}$ & a-tocopherol \\
\hline \multirow[t]{3}{*}{3} & \multicolumn{2}{|l|}{ Solubility } \\
\hline & Water soluble & $\begin{array}{l}\text { Haptoglobin, Ceruloplasmin, Albumin, Ascorbic } \\
\text { Acid, Uric acid, Albumin, Polyphenolic flavenoids, } \\
\text { Reduced glutathione \& other thiols, Cysteine \& } \\
\text { Transferrins }\end{array}$ \\
\hline & Lipid soluble & $\begin{array}{l}\text { a-tocopherol, Carotenoids, bilirubin, Ubiquinol and } \\
\text { Vitamin A }\end{array}$ \\
\hline 4 & $\begin{array}{l}\text { Repair De novo } \\
\text { enzymes }\end{array}$ & $\begin{array}{l}\text { DNA repair enzymes, Protease, Lipase and Trans- } \\
\text { ferase }\end{array}$ \\
\hline \multirow{4}{*}{5} & \multicolumn{2}{|c|}{ Structures they protect } \\
\hline & $\begin{array}{l}\text { DNA protective } \\
\text { antioxidants }\end{array}$ & $\begin{array}{l}\text { Superoxide dismutase enzymes } 1 \text { and } 2 \text {, Glutathi- } \\
\text { one peroxidase, DNA repair enzymes [e.g., } \\
\text { Poly(ADP-ribose) polymerase], Reduced glutathi- } \\
\text { one, Cysteine }\end{array}$ \\
\hline & $\begin{array}{l}\text { Protein-protec- } \\
\text { tive antioxidants }\end{array}$ & $\begin{array}{l}\text { Sequestration of transition metals by preventative } \\
\text { antioxidants } \\
\text { Antioxidant enzymes }\end{array}$ \\
\hline & $\begin{array}{l}\text { Lipid-protective } \\
\text { antioxidants }\end{array}$ & $\begin{array}{l}\text { a-Tocopherol (vitamin E), Ascorbate (vitamin C), } \\
\text { Carotenoids (including retinol - vitamin A), Reduced } \\
\text { ubiquinone, Reduced glutathione, Glutathione per- } \\
\text { oxidase, Bilirubin }\end{array}$ \\
\hline \multirow[t]{4}{*}{6} & \multicolumn{2}{|l|}{ By their origin } \\
\hline & $\begin{array}{l}\text { Exogenous anti- } \\
\text { oxidants }\end{array}$ & $\begin{array}{l}\text { Carotenoids, Ascorbic acid, Tocopherols }(a, b, c, d) \text {, } \\
\text { Polyphenols (e.g. Flavenoids, Catechins such as } \\
\text { Epigallocatechin-gallate), Folic acid, Cysteine }\end{array}$ \\
\hline & $\begin{array}{l}\text { Endogenous an- } \\
\text { tioxidants }\end{array}$ & $\begin{array}{l}\text { Catalase, Superoxide dismutase, Glutathione per- } \\
\text { oxidase, Glutathione-S-transferase, Reduced gluta- } \\
\text { thione, Ceruloplasmin, Transferrin, Ferritin, Glycosy- } \\
\text { lases, Peroxisomes, Proteases }\end{array}$ \\
\hline & Synthetic & $\mathrm{N}$-acetylcysteine, Penicillinamine, Tetracyclines \\
\hline
\end{tabular}




\section{Antioxidant enriched diet and periodontal diseases [25]}

Recent evidence has demonstrated a significant role for oxidative stress in promoting bone resorption via activation of certain transcription factors (Fox Os, which decreases want signalling), Modulated by insulin resistance and increasing age [26]. Antioxidant micronutrients combat such pro-inflammatory cascades through modulation of oxidative stress by directly scavenging Reactive Oxygen Species (ROS) and also by down-regulation of some redox-sensitive pro-inflammatory gene transcription factors such as nuclea factor-kappa B and activator protein-1 while up regulating anti-inflammatory gene transcription factors such as nuclear factor [5]. Following are some of the examples of antioxidant diets.

\section{Green Tea}

Green tea is a non-fermented product of tea (Camellina sinensis) leaves that is consumed as a beverage worldwide. Green tea extract is documented to have antibacterial, antioxidant, anti-inflammatory and anticarcinogenic properties. It is a rich source of flavonoids, mainly catechins. The four major catechins include

- Epigallocatechin-3-gallate (59\%)

- Epigallocatechin (19\%)

- Epicatechin-3-gallate (13.6\%)

- Epicatechin

Local drug delivery of green tea extract has also shown promising results in treating periodontal diseases [27]. Dentifrice and mouthwashes can be contemplated as vehicles for self-application of chemotherapeutics. Recently, the addition of green tea catechins to dentifrice has shown reduction of periodontal inflammation in the rat model, by decreasing gingival oxidative stress and expression of pro-inflammatory cytokines [28].

Hrishi et al., conducted a study to evaluate the effect of adjunctive use of green tea dentifrice in periodontitis patients and concluded that green tea dentrifice may serve as a beneficial adjunct to non-surgical periodontal therapy as it showed greater reduction of gingival inflammation and improved periodontal parameters on comparison with fluoride-triclosan dentrifice [29].

\section{Grape Seed Extracts (GSE)}

Grape seed extract is a naturally occurring polyphenolic compound obtained from seeds of Vitis vinifera. It possesses a wide range of biological activities such as immunomodulator agent, antioxidant, anticarcinogenic, and anti-inflammatory effects [30,31]. The immunomodulator effect is particularly due to its proanthocyanidin content. GSE may beneficial for the treatment of inflammation associated with bone destruction as it may strongly inhibit osteoclast differentiation, reduce osteoclast activity, and stimulate bone formation through its positive action on osteoblast differentiation [32]. The anti-inflammatory effect is modulated by calibrating the delicate balance between pro-inflammatory and anti-inflammatory cytokines through regulating their release and gene expression delicate balance between pro-inflammatory and anti-inflammatory cytokines through regulating their release and gene expression [33].

Ozden FO et al., investigated the effects of GSE application on periodontium before and after ligature induced experimental periodontitis [34], using histological and immunohistochemical analyses. Histopathological findings showed improvements in the inhibition of periodontal inflammation and destruction following GSE intake.
The bark contains magnolol and honokiol, two polyphenolic compounds that have been demonstrated as peroxisome proliferator-activated receptor gamma (PPAR gamma) agonists and gammaaminobutyric acid modulators. Magnolol extracted from Magnolia officinalis is widely used in oriental medicine. Preclinical studies have evaluated their various potential applications including antioxidant, anti-inflammatory, antitumor and antimicrobial properties [35].

Magnolol has been reported to have a potent anti-inflammatory activity via inhibition of proinflammatory cytokine, ROS formation, iNOS, COX-2 expression, and nuclear factor-kappaB (NF-kappaB) activation, a key transcription factor regulating inflammation, in LPS-induced inflammatory disease [36,37]. Furthermore, magnolol exerts a marked antimicrobial activity against periodontopathic bacteria and activates osteoblast function [38]. Magnolol may be used as a potential candidate for treating periodontitis.

$\mathrm{Lu} \mathrm{SH}$ et al., concluded in their study that magnolol significantly ameliorates the alveolar bone loss in ligature-induced experimental periodontitis by suppressing periodontopathic microorganism accumulation [39], NF- $\kappa$ B-mediated inflammatory mediator synthesis, RANKL formation, and osteoclastogenesis. These activities support that magnolol is a potential agent to treat periodontal disease.

\section{Melatonin}

Melatonin (N-acetyl-5-methoxy tryptamine) is a substance secreted by multiple organs including the pineal gland, retina, bone marrow, the gastro-intestinal track and the immune system. Because it is lipophilic, it can reach all body cells and cellular components rapidly [40]. In addition to its scavenger effects, melatonin indirectly stimulates various antioxidant enzymes $[41,42]$. A quality that makes melatonin superior to other antioxidants is that it does not become pro-oxidative by losing an electron during interactions with free radicals; i.e., it is not a potential pro-oxidant [43].

Local and systemic administration of melatonin in rats with lipopolysaccharide-induced periodontitis reduced the level of enzymes (such as serum aspartate aminotransferase, alanine transaminase and blood urea nitrogen) significantly compared with rats in the control group $[42,44]$. Similarly, locally administered melatonin significantly reduced bone resorption compared with rats receiving no treatment. These studies suggested that topical administration of melatonin can be used as an adjunct to conventional treatment protocols such as scaling, root planing, and surgical debridement to improve the outcomes of periodontal therapy.

\section{Propolis Extract}

Propolis, sometimes called bee glue, is a natural resinous substance collected by honey bees (Apis mellifera L.) from plant buds and bark exudates. Bio-flavonols are the key contributors to propolis' properties. Propolis is found to have strong inhibitory effects on at least 21 species of bacteria, 9 species of fungi, 3 species of protozoa, and a wide range of viruses.

A number of studies have presented evidence that propolis has strong hepatoprotective, antitumor, antioxidative, antimicrobial and anti-inflammatory properties. Coutinho A in the year 2012 in their clinical study demonstrated the benefits provided by propolis extract and indicated that it should be considered for use as an adjuvant to scaling and root planing [45-48]. 
Citation: Rudrakshi C, Prabhuji MLV, Parween S, Jyothsna S (2017) Relationship between Antioxidants and the Development of the Periodontal Disease. J Cytol Tissue Biol 4: 016.

\section{Salivary Antioxidant Status}

Saliva is rich in antioxidants, mainly uric acid accounting for more than $70 \%$ of the total antioxidant activity of resting and stimulated saliva from both healthy and periodontally compromised subjects. Other antioxidants present in lesser concentration than uric acid are albumin, ascorbate and glutathione [49]. Albumin concentration is comparatively low, about $10 \mathrm{mM}$, apparently in the same range of that of ascorbic acid $[49,50]$. Accounting for the $5-10 \%$ of antioxidant activity in saliva are the traces of other antioxidants such as transferrin, lactoferrin and caeruloplasmin. They are capable of binding metal ions are found in both saliva and GCF [51].

\section{Antioxidant status in gingival crevicular fluid}

An excess of reactive oxygen species and depletion of antioxidant levels in gingival crevicular fluid are responsible for the chronic local activation of periodontal inflammation and tissue destruction [5,52]. Gingival crevicular fluid probably contains a locally derived antioxidant from local three sources such as plaque bacteria, neutrophils and crevicular epithelium [53].

Significantly more intense levels of superoxide dismutases in gingival crevicular fluid comprise the most important antioxidant enzyme defense system against reactive oxygen species.

The reduced and oxidised glutathione concentrations in the gingival crevicular fluid are significantly lower in patients with chronic periodontitis, supporting that the glutathione levels in gingival crevicular fluid can play an important role in the pathogenesis of periodontitis [54].

\section{Total antioxidant capacity}

It is the measure of the antioxidant capacity of all antioxidants in a biological sample rather than the antioxidant capacity of a single compound. Total Antioxidant Capacity (TAC) of saliva has been measured by only 3 methods using 3 different biochemical techniques [55];

- Spectrophotometric assay

- Enhanced chemiluminescence assay

- Cyclic voltammetry assay

Salivary TAC decreases or does not changes in periodontal disease.

\section{Mechanism of Action [5,15]}

\section{Superoxide Dismutase (SOD)}

It is an anti-oxidative enzyme, which has been localized within human periodontal ligament and represent an vital defense mechanism for gingival fibroblasts against superoxide ions by catalyzing and accelerating the reaction (approximately 10,000 times) from superoxide ion to oxygen and less reactive $\mathrm{H}_{2} \mathrm{O}_{2}$ (Figure 3).

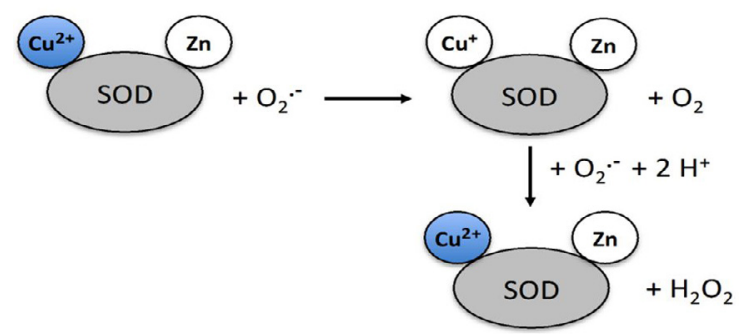

Figure 3: Mechanism of action of superoxide dismutase.
In humans SOD exists in 3 forms (Figures 4 and 5)

- Cytosolic Cu/Zn-SOD,

- Mitochondrial Mn-SOD (major role)

- Extracellular SOD (EC-SOD)
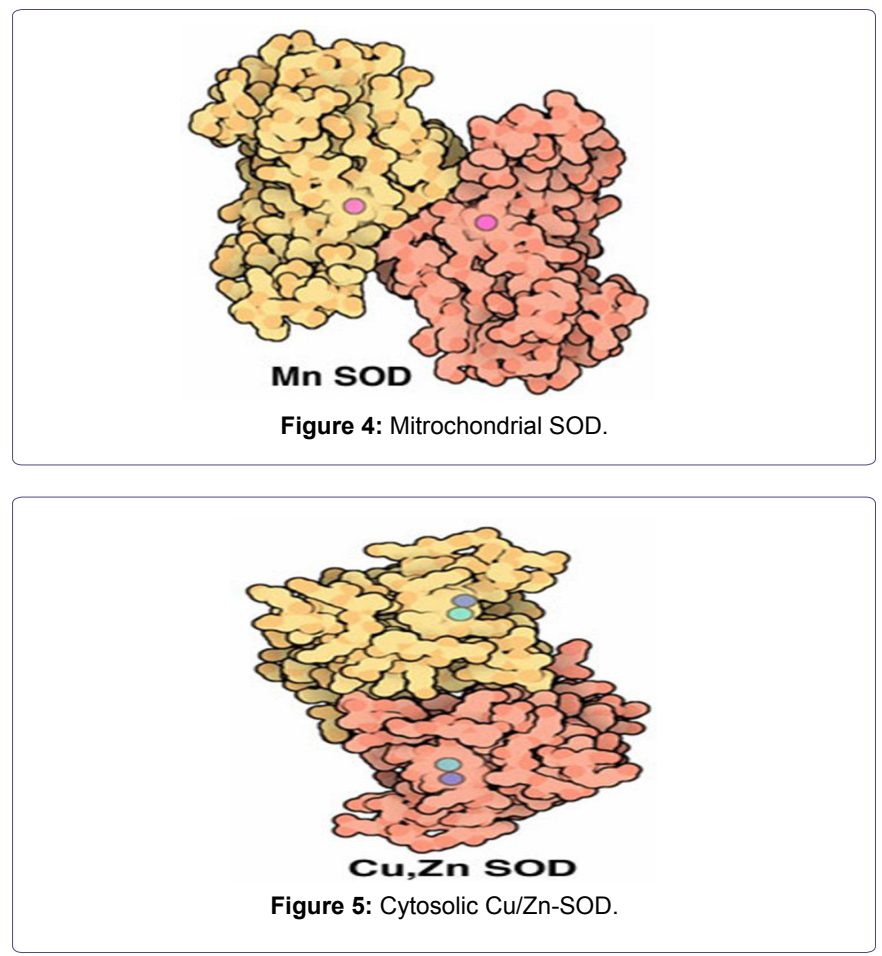

\section{Catalase (CAT)}

It is heme bound iron anti-oxidative enzyme, majorly located in peroxisomes. It protects the cells from hydrogen peroxide by converting it into water (Figure 6).

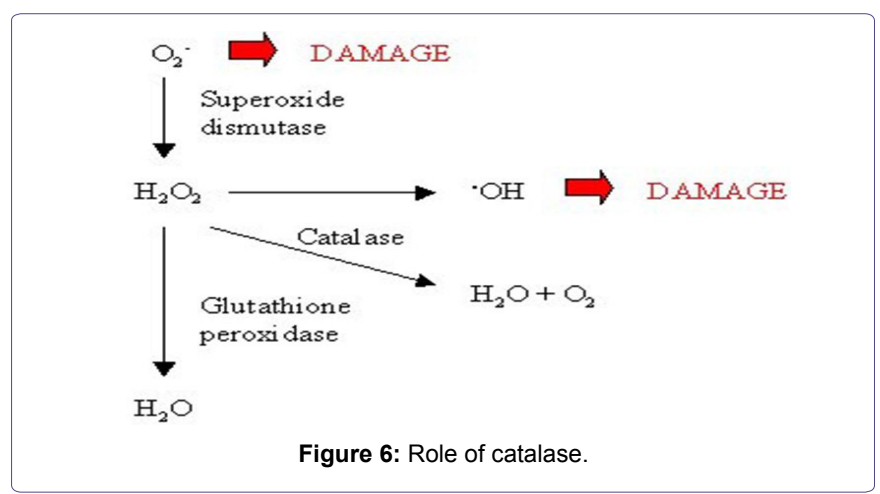

\section{Reduced Glutathione (GSH)}

GSH is an essential antioxidant enzyme, which AIDs as A- Anti-oxidant, I-Immunobooster, D- Detoxifier. It regulates IL-2 dependent $\mathrm{T}$ lymphocyte proliferation (Figure 7).

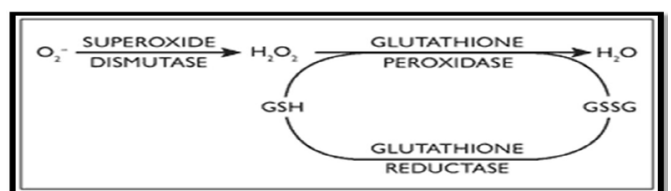

Figure 7: Role of glutathione. 
Citation: Rudrakshi C, Prabhuji MLV, Parween S, Jyothsna S (2017) Relationship between Antioxidants and the Development of the Periodontal Disease. J Cytol Tissue Biol 4: 016.

\section{Glutathione Peroxidase}

It is a selenium containing peroxidase which reduces variety of hydroperoxides, $\mathrm{H}_{2} \mathrm{O}_{2}$ and lipids, there by protects the cell particularly against low levels of oxidative stress. It has 5 types of isoezymes, these are GPX1, GPX2, GPX3, GPX4, and GPX5.

\section{Uric acid}

Moore et al., in 1994 proposed that uric acid is responsible for $70 \%$ antioxidants capacity of saliva and it is one of the major antioxidant present in saliva. Diab-Ladki in 2003 [56] found decreased concentrations of uric acid, ascorbic acid and albumin in saliva of periodontitis patients.

\section{Ascorbic acid (vitamin C)}

It is a water soluble vitamin, function as antioxidant by scavenging water-soluble peroxyl radicals, scavenging superoxide and perhydroxyl radicals, prevention of damage mediated by hydroxyl radicals on uric acid, scavenger of hypochlorous acid, decreases heme breakdown and subsequent $\mathrm{Fe}^{2+}$ release thereby preventing Fenton reactions, scavenger of singlet oxygen and hydroxyl radicals, re-forms a-tocopherol from its radical and also protects against ROS-release from cigarette smoke.

\section{Conclusion}

Following conclusion can be drawn with respect to the role of reactive oxygen species and antioxidants in periodontitis

1. Oxidative stress and reactive oxygen species appear to play a significant role in the patho-physiology of periodontal diseases.

2. Adjunctive use of antioxidants with traditional therapies should be considered to improve the periodontal treatment outcome.

3. This review presents with evidence within the biomedical literature, provides exciting new opportunities for future development of host modulation therapies in periodontology.

\section{Future Research Directions}

The results of the review may have relevance for the development of treatment protocols. The impact of the combination of periodontal therapy with antioxidants in terms of antioxidant/oxidative stress parameters requires further investigation with longer follow.

\section{References}

1. Lamster IB, Novak MJ (1992) Host mediators in gingival crevicular fluid: Implications for the pathogenesis of periodontal disease. Crit Rev Oral Bio Med 3: 31-60.

2. Bray TM (1999) Antioxidants and Oxidative Stress in Health and Disease: Introduction. Proc Soc Exp Biol Med 222: 195.

3. Pham-Huy LA, He H, Pham-Huy C (2008) Free radicals, antioxidants in disease and health. Int J Biomed Sci 4: 89-96.

4. Downey GP, Fukushima T, Fialkow L (1995) Signaling mechanisms in human neutrophils. Curr Opin Hematol 2: 76-88.

5. Chapple IL, Matthews JB (2007) The role of reactive oxygen and antioxidant species in periodontal tissue destruction. Periodontol 2000 43: 160-232.

6. Basu S, Helmersson J, Jarosinska D, Sällsten G, Mazzolai B, et al (2009) Regulatory factors of basal F(2)-isoprostane formation: population, age, gender and smoking habits in humans. Free Radic Res 43: 85-91.
7. Cekici A, Kantarci A, Hasturk H, Van Dyke TE (2014) Inflammatory and immune pathways in the pathogenesis of periodontal disease. Periodontol 2000 64: 57-80.

8. Dennison DK, Van Dyke TE (1997) The acute inflammatory response and the role of phagocytic cells in periodontal health and disease. Periodontol 2000 14: 54-78.

9. Eke PI, Dye BA, Wei L, Slade GD, Thornton-Evans GO, et al. (2015) Update on prevalence of periodontitis in adults in the United States: NHANES 2009 to 2012. J Periodontol 86: 611-622.

10. Engebretson S, Kocher T (2013) Evidence that periodontal treatment improves diabetes outcomes: A systematic review and meta-analysis. J Clin Periodontol 40: 153-163.

11. Jin LJ, Lamster IB, Greenspan JS, Pitts NB, Scully C, et al. (2016) Global burden of oral diseases: Emerging concepts, management and interplay with systemic health. Oral Dis 22: 609-619.

12. Buset SL, Walter C, Friedmann A, Weiger R, Borgnakke WS, et al. (2016) Are periodontal diseases really silent? A systematic review of their effect on quality of life. J Clin Periodontol 43: 333-344.

13. Jeffcoat MK, Jeffcoat RL, Gladowski PA, Bramson JB, Blum JJ (2014) Impact of periodontal therapy on general health: Evidence from insurance data for five systemic conditions. Am J Prev Med 47: 166-174.

14. Halliwell B (1997) Antioxidants: The basics--what they are and how to evaluate them. Adv Pharmacol 38: 3-20.

15. Sree SL, Mythili R (2011) Antioxidants in Periodontal Diseases : A Review. Indian J Multidiscip Dent 1: 140-146.

16. Chengcheng Liu, Longyi Mo, Yulong Niu, Xin Li, Xuedong Zhou, et al. (2017) The Role of Reactive Oxygen Species and Autophagy in Periodontitis and Their Potential Linkage. Front Physiol 8: 439.

17. Dahiya P, Kamal R, Gupta R, Bhardwaj R, Chaudhary K, et al. (2013) Reactive oxygen species in periodontitis. J Indian Soc Periodontol 17: 411-416.

18. Halliwell B (1989) Free radicals, reactive oxygen species and human disease: A critical evaluation with special reference to atherosclerosis. Br J Exp Pathol 70: 737-757.

19. Pendyala G, Thomas B, Kumari S (2008) The challenge of antioxidants to free radicals in periodontitis. J Indian Soc Periodontol 12: 79-83.

20. Sharma A, Wati S, Sharma S (2011) Reactive oxygen species and antioxidants in periodontics : A Review. Int J Dent Clin 3: 44-47.

21. Agnihotri R, Pandurang P, Kamath SU, Goyal R, Ballal S, et al. (2009) Association of cigarette smoking with superoxide dismutase enzyme levels in subjects with chronic periodontitis. J Periodontol 80: 657-662.

22. Patil VS, Patil VP, Gokhale N, Acharya A, Kangokar P (2016) Chronic Periodontitis in Type 2 Diabetes Mellitus: Oxidative Stress as a Common Factor in Periodontal Tissue Injury. J Clin Diagn Res 10: 12-16.

23. Di Meo S, Reed TT, Venditti P, Victor VM (2016) Role of ROS and RNS Sources in Physiological and Pathological Conditions. Oxid Med Cell Longev 2016: 1245049.

24. He ZJ, Zhu FY, Li SS, Zhong L, Tan HY, et al. (2017) Inhibiting ROSNF-KB-dependent autophagy enhanced brazilin-induced apoptosis in head and neck squamous cell carcinoma. Food Chem Toxicol 101: 55-66.

25. Muniz FW, Nogueira SB, Mendes FL, Rösing CK, Moreira MM, et al (2015) The impact of antioxidant agents complimentary to periodontal therapy on oxidative stress and periodontal outcomes: A systematic review. Arch Oral Biol 60: 1203-1214.

26. Galli C, Passeri G, Macaluso GM (2011) FoxOs, Wnts and oxidative stress-induced bone loss: new players in the periodontitis arena? J Periodontal Res 46: 397-406. 
Citation: Rudrakshi C, Prabhuji MLV, Parween S, Jyothsna S (2017) Relationship between Antioxidants and the Development of the Periodontal Disease. J Cytol Tissue Biol 4: 016.

27. Hirasawa M, Takada K, Makimura M, Otake S (2002) Improvement of periodontal status by green tea catechin using a local delivery system: a clinical pilot study. J Periodontal Res 37: 433-438.

28. Kudva P, Tabasum ST, Shekhawat NK (2011) Effect of green tea catechin a local drug delivery system as an adjunct to scaling and root planing in chronic periodontitis patients: A clinicomicrobiological study. J Indian Soc Periodontol 15: 39-45.

29. Hrishi TS, Kundapur PP, Naha A, Thomas BS, Kamath S, et al. (2016) Effect of adjunctive use of green tea dentifrice in periodontitis patients - A randomized controlled pilot study. Int J Dent Hyg 14: 178-183.

30. Baydar NG, Sagdic O, Ozkan G, Cetin S (2006) Determination of antibacterial effects and total phenolic contents of grape (Vitis vinifera L.) seed extracts. Int J Food Sci Tech 41: 799-804.

31. Zhang XY, Bai DC, Wu YJ, Li WG, Liu NF (2005) Proanthocyanidin from grape seeds enhances anti-tumor effect of doxorubicin both in vitro and in vivo. Pharmazie 60: 533-538.

32. Park JS, Park MK, Oh HJ, Woo YJ, Lim MA, et al. (2012) Grape-seed proanthocyanidin extract as suppressors of bone destruction in inflammatory autoimmune arthritis. PLoS One 7: 51377.

33. Ahmad SF, Zoheir KM, Abdel-Hamied HE, Attia SM, Bakheet SA, et al (2014) Grape seed proanthocyanidin extract protects against carrageenan-induced lung inflammation in mice through reduction of pro-inflammatory markers and chemokine expressions. Inflammation 37: 500-511.

34. Özden FO, Sakallioğlu EE, Sakallioğlu U, Ayas B, Erișgin Z (2017) Effects of grape seed extract on periodontal disease: an experimental study in rats. J Appl Oral Sci 25: 121-129.

35. Shen JL, Man KM, Huang PH, Chen WC, Chen DC, et al. (2010) Honokio and magnolol as multifunctional antioxidative molecules for dermatologic disorders. Molecules 15: 6452-6465.

36. Yang TC, Zhang SW, Sun LN, Wang H, Ren AM (2008) Magnolol attenuates sepsis-induced gastrointestinal dysmotility in rats by modulating inflammatory mediators. World J Gastroenterol 14: 7353-7360.

37. Tsai YC, Cheng PY, Kung CW, Peng YJ, Ke TH, et al. (2010) Beneficial effects of magnolol in a rodent model of endotoxin shock. Eur J Pharmacol 641: 67-73.

38. Kwak EJ, Lee YS, Choi EM (2012) Effect of Magnolol on the Function of Osteoblastic MC3T3-E1 Cells. Mediators of Inflammation 2012: 829650.

39. Lu SH, Huang RY, Chou TC (2013) Magnolol ameliorates ligature-induced periodontitis in rats and osteoclastogenesis: In vivo and in vitro study. Evid Based Complement Alternat Med 2013: 634095

40. Menendez-Pelaez A, Poeggeler B, Reiter RJ, Barlow-Walden L, Pablos MI, et al. (1993) Nuclear localization of melatonin in different mammalian tissues: Immunocytochemical and radioimmunoassay evidence. J Cell Biochem 53: 373-382.

41. Kara A, Akman S, Ozkanlar S, Tozoglu U, Kalkan Y, et al. (2013) Immune modulatory and antioxidant effects of melatonin in experimental periodontitis in rats. Free Radic Biol Med 55: 21-26.
42. Arabacı T, Kermen E, Özkanlar S, Köse O, Kara A, et al. (2015) Therapeutic effects of melatonin on alveolar bone resorption after experimental periodontitis in rats: A biochemical and immunohistochemical study. J Periodontol 86: 874-881.

43. Czesnikiewicz-Guzik M, Konturek SJ, Loster B, Wisniewska G, Majewski $S$ (2007) Melatonin and its role in oxidative stress related diseases of oral cavity. J Physiol Pharmacol 58: 5-19.

44. Gulle K, Akpolat M, Kurcer Z, Cengiz MI, Baba F, et al. (2014) Multi-organ injuries caused by lipopolysaccharide-induced periodontal inflammation in rats: role of melatonin. J Periodontal Res 49: 736-741.

45. Banskota AH, Tezuka Y, Kadota S (2001) Recent progress in pharmacological research of propolis. Phytother Res 15: 561-571.

46. Sforcin JM (2007) Propolis and immune system: A review. J Ethnopharmacol 113: 1-14.

47. Martos VM, Navajas RY, Fernandez LJ, Alvarez JA (2008) Functional properties of honey, propolis, and royal jelly. J Food Sci 73: 117-124.

48. Coutinho A (2012) Honeybee propolis extract in periodontal treatment: a clinical and microbiological study of propolis in periodontal treatment. Indian J Dent Res 23: 294.

49. Phaniendra A, Jestadi DB, Periyasamy L (2015) Free radicals: Properties, sources, targets, and their implication in various diseases. Indian $\mathrm{J}$ Clin Biochem 30: 11-26.

50. Moore S, Calder KA, Miller NJ, Rice-Evans CA (1994) Antioxidant activity of saliva and periodontal disease. Free Radic Res 21: 417-425.

51. Lynch E, Sheerin A, Claxon AW, Atherton MD, Rhodes CJ, et al. (1997) Multicomponent spectroscopic investigations of salivary antioxidant consumption by an oral rinse preparation containing the stable free radical species chlorine dioxide (CIO2.). Free Radic Res 26: 209-234.

52. Chapple IL (1997) Reactive oxygen species and antioxidants in inflammatory diseases. J Clin Periodontol 24: 287-296.

53. Chapple ILC, Brock G, Eftimiadi C, Matthews JB (2002) Glutathione in gingival crevicular fluid and its relation to local antioxidant capacity in periodontal health and disease. Mol Pathol 55: 367-373.

54. Öngöz DF, Bozkurt DS, Balli U, Avci B, Durmușlar MC, et al. (2016) Glutathione levels in plasma, saliva and gingival crevicular fluid after periodontal therapy in obese and normal weight individuals. J Periodont Res 51: 726734.

55. Kusano C, Ferrari B (2008) Total Antioxidant Capacity: A biomarker in biomedical and nutritional studies. J Mol Cell Biol 7: 1-15.

56. Diab-Ladki R, Pellat B, Chahine R (2003) Decrease in the total antioxidant activity of saliva in patients with periodontal diseases. Clin Oral Investig 7: 103-107. 
Citation: Rudrakshi C, Prabhuji MLV, Parween S, Jyothsna S (2017) Relationship between Antioxidants and the Development of the Periodontal Disease. J Cytol Tissue Biol 4: 016.

- Page 8 of 7 • 
Citation: Rudrakshi C, Prabhuji MLV, Parween S, Jyothsna S (2017) Relationship between Antioxidants and the Development of the Periodontal Disease. J Cytol Tissue Biol 4: 016.

- Page 9 of 7 • 